\title{
A new genus and species of Bruchinae, with a key to the genera from Australia (Coleoptera: Chrysomelidae)
}

\author{
C. A. M. REID \& M. BEATSON \\ Department of Entomology, Australian Museum, 6 College Street, Sydney, NSW 2010, Australia. Email: chris.reid@austmus.gov.au; \\ max.beatson@austmus.gov.au
}

\begin{abstract}
A new genus of Bruchinae, Buburra Reid \& Beatson, is erected for a single new species, B. jeanae Reid \& Beatson. Buburra is endemic to Australia where it is known from a single site at high altitude in Victoria. The hostplant is unknown. Buburra is placed in the tribe Pachymerini. A key is provided for identification of the 12 genera of Bruchinae in Australia, including Caryotrypes Decelle, 1968, recorded from Australia for the first time. Five Australian species described in Bruchus Linneus, 1767, are newly transferred to Bruchidius Schilsky, 1905: Bruchidius diversipes (Lea, 1899) comb. nov.; B. maestus (Lea, 1899) comb. nov.; B. oodnadattae (Blackburn, 1900) comb. nov.; B. persimulans (Blackburn, 1900) comb. nov.; $B$. quornensis (Blackburn, 1900) comb. nov. A checklist is provided for the species of Bruchinae in Australia.
\end{abstract}

Key words: seed beetle, morphology, taxonomy, biocontrol, pest species

\section{Introduction}

The subfamily Bruchinae is of moderate size worldwide, with at least 1700 species (Johnson, Southgate \& Delobel 2004), and most of its species feed on leguminous seeds as larvae (Southgate 1979; Borowiec 1987). It should therefore be diverse in Australia, where there are more than 2300 species of Fabaceae, including Mimosoideae and Caesalpinoideae (Orchard 1999). However, the Australian bruchine fauna is depauperate, with only 12 described native species (Udagiri \& Wadhi 1989; Anton 2000; Appendix A) and a further 30-40 native species represented in collections (pers. obs., CAMR).

Worldwide, there are six tribes of Bruchinae, three monotypic and restricted to central Asia (Rhaebini), central South America (Eubaptini) and the temperate Holarctic (Kytorhinini) (Southgate 1979; Borowiec 1987; Kergoat et al. 2008; Delobel \& Lagalov 2009). In Australia, three tribes have been recorded: Amblycerini, Bruchini and Pachymerini. The easily distinguished Amblycerini (Borowiec 1987) are represented by a single genus and two species. Bruchini dominate in numbers of genera and species, as they do elsewhere. No native Pachymerini are recorded from Australia, but one was introduced accidentally a long time ago and is well-established in the tropics (Brooks 1969; Delobel, Sembène, Fédière \& Roguet 2003). We have seen a single specimen of a second genus from the far north coast. Pachymerini feed primarily on palms in South America and on tropical legumes and pandanus in Africa and southern Asia (Nilsson \& Johnson 1993; Anton1999a).

Therefore the senior author was surprised to collect a short series of a pachymerine from $1450 \mathrm{~m}$ up a mountain in Victoria, far from the tropics $\left(36^{\circ} \mathrm{S}\right)$, in November, 2010 (Fig. 1). First consideration was that this was a biocontrol agent introduced by one of the weed control agencies in Australia. Bruchines are at the forefront of weed control in Australia as they are commonly host-specific and they attack seeds, reducing the next generation (Julien \& Griffiths 1999). The possibility of an introduction was eliminated by the discovery that (i) no pachymerines have been introduced for biocontrol; (ii) the beetles could not be identified to genus using either of the published keys (Borowiec 1987; Nilsson \& Johnson 1993). A second trip was made in November, 2011, to the same locality and a few additional specimens obtained.

This beetle is not identifiable to genus in the only key to world genera (Borowiec 1987). From that, it fits Pachymerini and appears to be most similar to Mimocaryedon Decelle, 1968, in subtribe Caryedontina, but it does 
not fit definitions of either this subtribe or this genus (Borowiec 1987; Johnson, Southgate \& Delobel 2004). From the key to world genera of Pachymerini (Nilsson \& Johnson 1993), the beetle appears to belong to subtribe Caryopemina, but it differs from the two described genera in numerous features, including several probable plesiomorphies (procoxal cavity closure, complex wing venation, 2 tibial spurs, male genitalic structure). The tribe Pachymerini as understood by Nilsson and Johnson (1993) is probably not monophyletic: Pachymerini is defined by a plesiomorphic state, a broad mesepimeron (Borowiec 1987) typical of Chrysomelidae in general, or by body and appendage proportions (Nilsson \& Johnson 1993) which have weak phylogenetic signal at best. Here the new genus is tentatively placed in Pachymerini, without allocation to a subtribe.

The type locality, Mount Buffalo, is well-known for three endemic species of plants and an endemic subspecies of butterfly (Grey \& Grey 1998). The discovery of Buburra there suggests many more endemic species remain to be found.

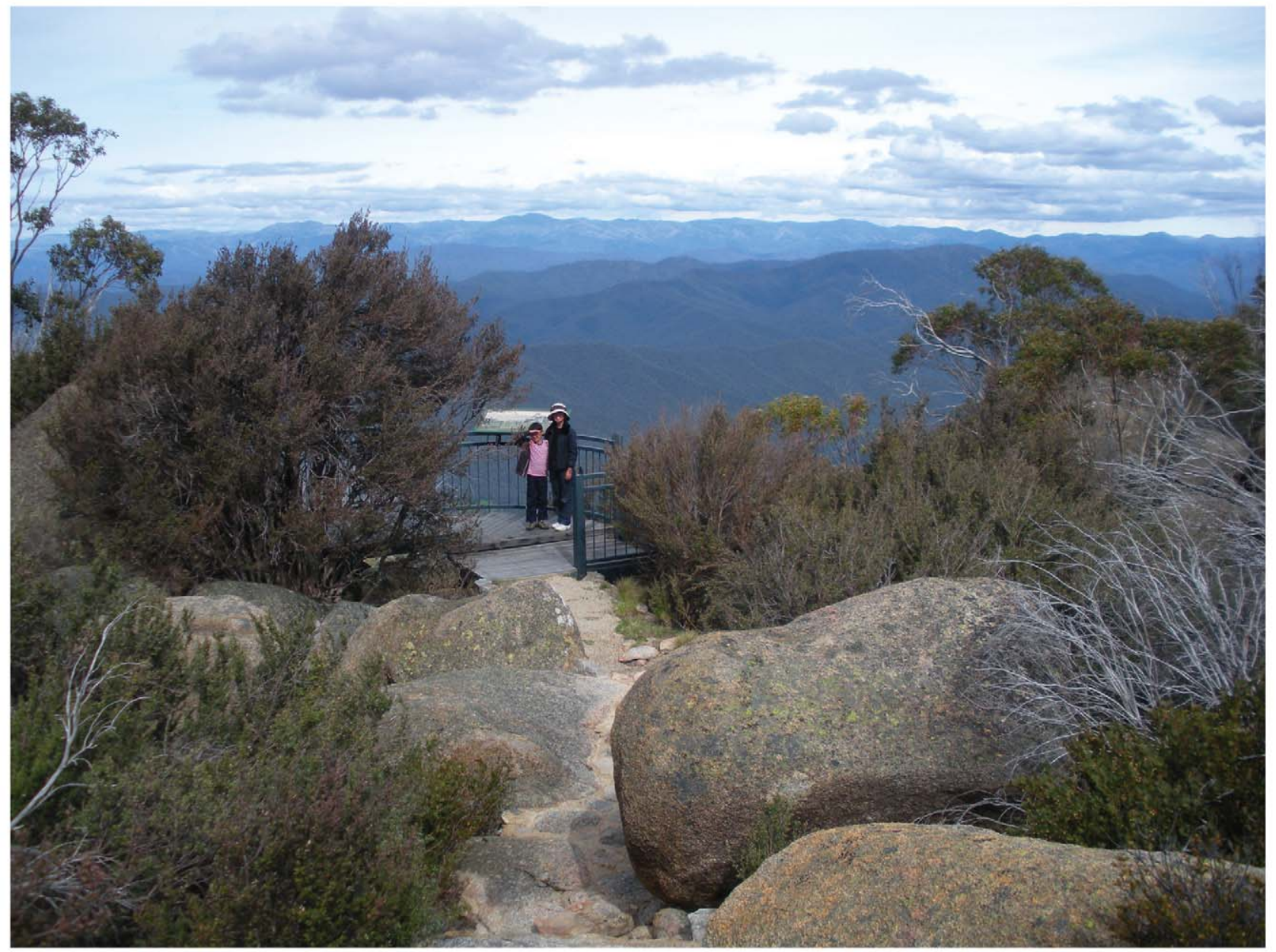

FIGURE 1. Type locality of Buburra jeanae Reid \& Beatson, Dixons Falls lookout, Mount Buffalo National Park, 15 November 2010. Phebalium squamulosum ssp. alpinum at right foreground. Photograph by J. Reid.

\section{Methods}

Genitalia were dissected from abdomens washed in water after being soaked in cold $10 \% \mathrm{KOH}$ overnight. After examination they were stored in glycerol in a microvial, pinned with the rest of the specimen. Morphological terminology is based on Lawrence, Beutel, Leschen \& Slipinski (2010).

Abbreviations: AMS (Australian Museum, Sydney), ANIC (Australian National Insect Collection, Canberra), MHNP (Natural History Museum, Paris), MVM (Museum of Victoria, Melbourne), NP (National Park), NSW (New South Wales), SAM (South Australian Museum, Adelaide). 


\section{Buburra Reid \& Beatson, gen. nov.}

(Figures 2-25)

Type species: Buburra jeanae Reid \& Beatson, this designation.

Diagnosis. Frons without median ridge; eyes small, with moderately deep canthus, approximately $1 / 3$ greatest eye diameter; eye facets small; temples long, $1 / 22^{2 / 3}$ eye length, posteriorly rounded; antennomeres not sexually dimorphic, not conspicuously serrate; venter of head without well-defined submental area; pronotum subrectangular, entirely laterally marginate; prosternal process long and narrow, visible and strongly arched between coxae and terminating behind them; mesepimeron broad, evenly narrowing from anterolateral edge to posteromedial edge; apex hind femora with ventral pecten of 6-9 large blunt spines on outer margin; fore and mid tibiae with 2 short apical spurs; hind tibia ventral surface without basal tubercle, apex without spurs; first ventrite as long as $2-4$ combined; apical lobes tegmen membranous, bilobed and setose at apex; apex penis acute, rigid (strongly sclerotised), without valves; female without spines in bursa copulatrix.

Description. Sexes externally similar. Body (Figs 2-5): small for a pachymerine, total length $3.8-4.5 \mathrm{~mm}$ (with head flat), length from anterior of pronotum to apex elytra $3.4-3.9 \mathrm{~mm}$, elongate-oval; integument mostly reddishbrown, variegated on elytra, generally with covering of adpressed setae, not dense enough to obscure integument, which is mostly densely and finely punctured (conspicuous large scattered punctures absent); two types of setae present, erect and adpressed; adpressed setae variegated on elytra in small pale or dark patches.

Head (Figs 2-3, 6, 17-18): elongate, not concealed from above, width at eyes much less than twice (c.1.3x) width at neck; neck, vertex and frons level, without abrupt elevation between neck and vertex; frons without median ridge but midline partially less punctate and microsculptured, shallowly impressed around inner margin of eyes; clypeus almost quadrate; eyes small but extending to venter of head, interocular distance dorsally $>$ dorsal eye width (c.1.3x) and ventrally > eye width (c. $2.4 \mathrm{x}$ ); eyes with deep canthus at antennal insertions, approximately $1 / 3$ greatest eye diameter; eye facets small, basal width of second antennomere equal to approximately two facet diameters; temples long, $1 / 22^{2} / 3$ length eye in lateral view, posteriorly rounded; antennae moderately long, approximately $2 / 3$ body length, inserted laterally, in swellings at junction of clypeus and frons; all antennomeres elongate, 1 ovate with truncate apex, 2-5 relatively narrow with rounded apices, 6-10 expanded with truncate apices but not conspicuously serrate, 11 elongate-acuminate, inner edge 7 bluntly lobed at apex; labrum large, semi-ovate; mandibles flat, with acutely unidentate apices projecting beyond labrum; apical maxillary palpomere elongate-fusiform, 1.6-1.8x length penultimate; mentum transversely rectangular (width c. $3 \mathrm{x}$ length) with blunt anterolateral lobes; venter of head dull and sculptured from between temples to mentum, without sutures or defined 'submentum', smooth and shining posterior to this.

Thorax (Figs 2-5, 7-9): pronotal dorsal shape subrectangular, slightly transverse, hind angles blunt, basal 2/3 almost parallel, apical $1 / 3$ contracting to prominent trichobothrium at anterior angles; lateral carina (margination) present from base to apex; surface elevated at middle of anterior, slightly depressed either side of disc; prosternal process long and narrow, strongly arched between coxae, flat and slightly expanded at apex posterior to coxae; coxal cavities closed by junction of thin hypomeral lobe reaching tip of prosternal process; scutellum small, acutely triangular with rounded tip; each elytron elongate, covering or almost covering (male) or exposing (female) pygidium, flat at base, without elevated spines or tubercles; 10 deeply grooved striae present, obscurely punctate, $1^{\text {st }}, 2^{\text {nd }}, 3^{\text {rd }}, 8^{\text {th }}, 9^{\text {th }}$ straight from elytral base to apex, $4^{\text {th }}$ and $5^{\text {th }}$ usually anastomosed and always terminating $2 / 3$ from base, $6^{\text {th }} \& 7^{\text {th }}$ usually anastomosed at apex ( 6 fused with $4+5$ on one elytron), $10^{\text {th }}$ adjacent to epipleural margin; upper margin epipleuron distinct at base, evanescent in apical third; mesoventrite with gradually elevated elongate parallel-sided process between coxae, apex truncate; mesepimeron broad, evenly narrowing from anterolateral edge to posteromedial edge, which is c. $1 / 2$ width anterolateral edge; wing venation relatively complete for Bruchinae, median field of wing with closed elongate basal cell, two apical veins leading off this, short AA4 and long $\mathrm{CuA} 2$ reaching wing margin, plus two free veins reaching wing margin (probably MP3 and MP4); metaventrite discrimen distinct on basal 3/4; metanepisterna elongate rectangular; procoxae conical but not elevated above prosternal process, mid coxae ovate, hind coxae slightly smaller than hind femora; mid and anterior femora elongate-fusiform without ventral keels; hind femora elongate-ovate, middle $1 / 2-3 / 4$ of venter with irregular median row of 15-22 small spines slightly increasing in size towards apex, and apical quarter with pecten of 6-9 large blunt spines on outer margin, the most basal spine slightly largest; fore and mid tibiae thin, without keels, apices with 2 short spurs each c. $0.5 \mathrm{x}$ apical tibial width; hind tibia strongly curved, ventral surface sharply keeled along 
entire inner and outer edges and without basal tubercle, trace of short lateral keel at base, apex with ventral short flat triangular projection, length $0.3-0.5 \mathrm{x}$ apical tibial width, without spurs; tarsi 5-segmented, long and thin, hind tarsi almost as long as hind tibiae; first tarsomere elongate and narrow (male $=$ female), third tarsomere transverse, bilobed, lobes $0.3-0.5 \mathrm{x}$ total length, claws ventrally bluntly lobed.
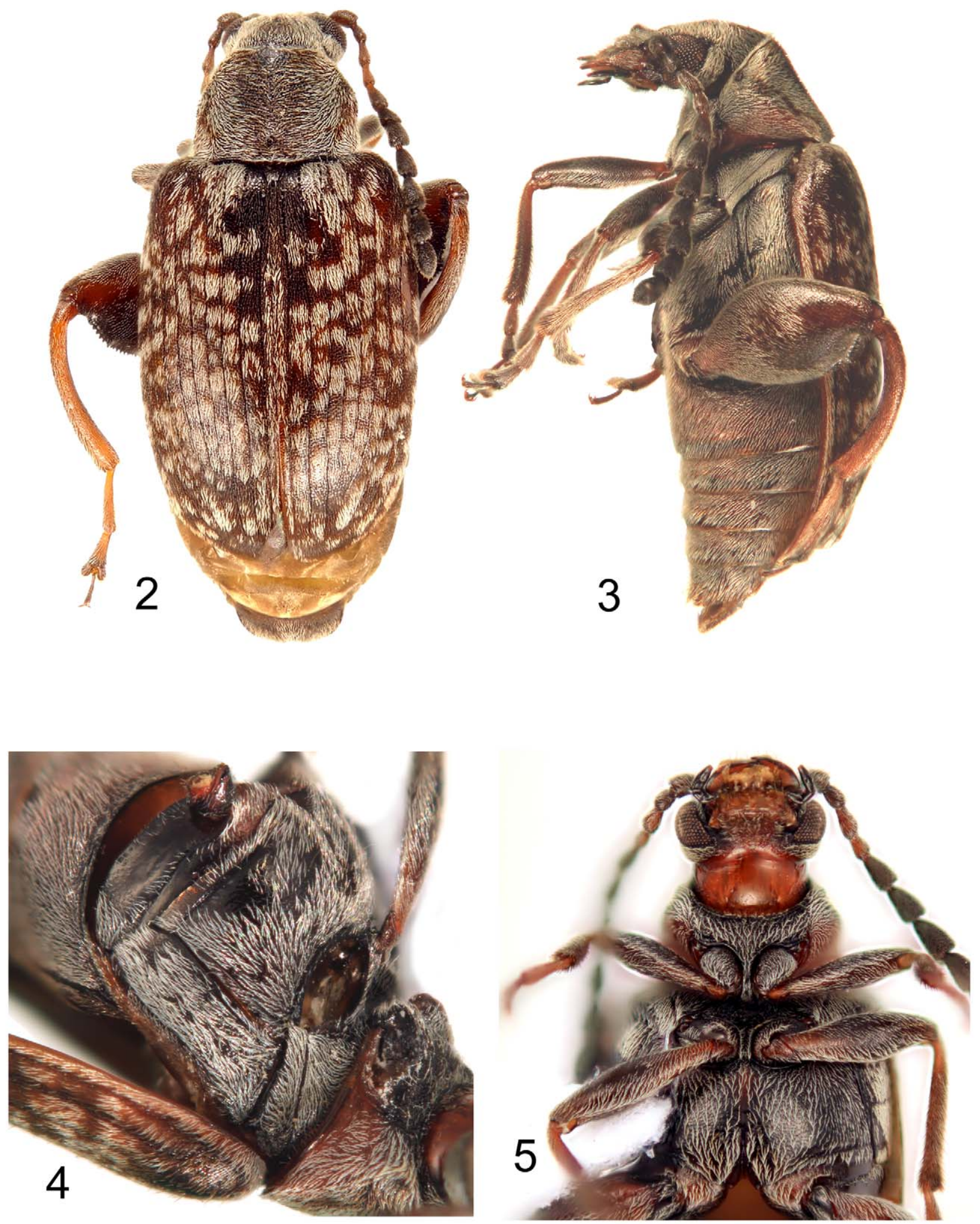

FIGURES 2-5. Buburra jeanae Reid \& Beatson: 2, dorsal; 3, lateral; 4, lateroventral of thorax with legs removed, including pro- and mesocoxae; 5 , ventral of thorax. 

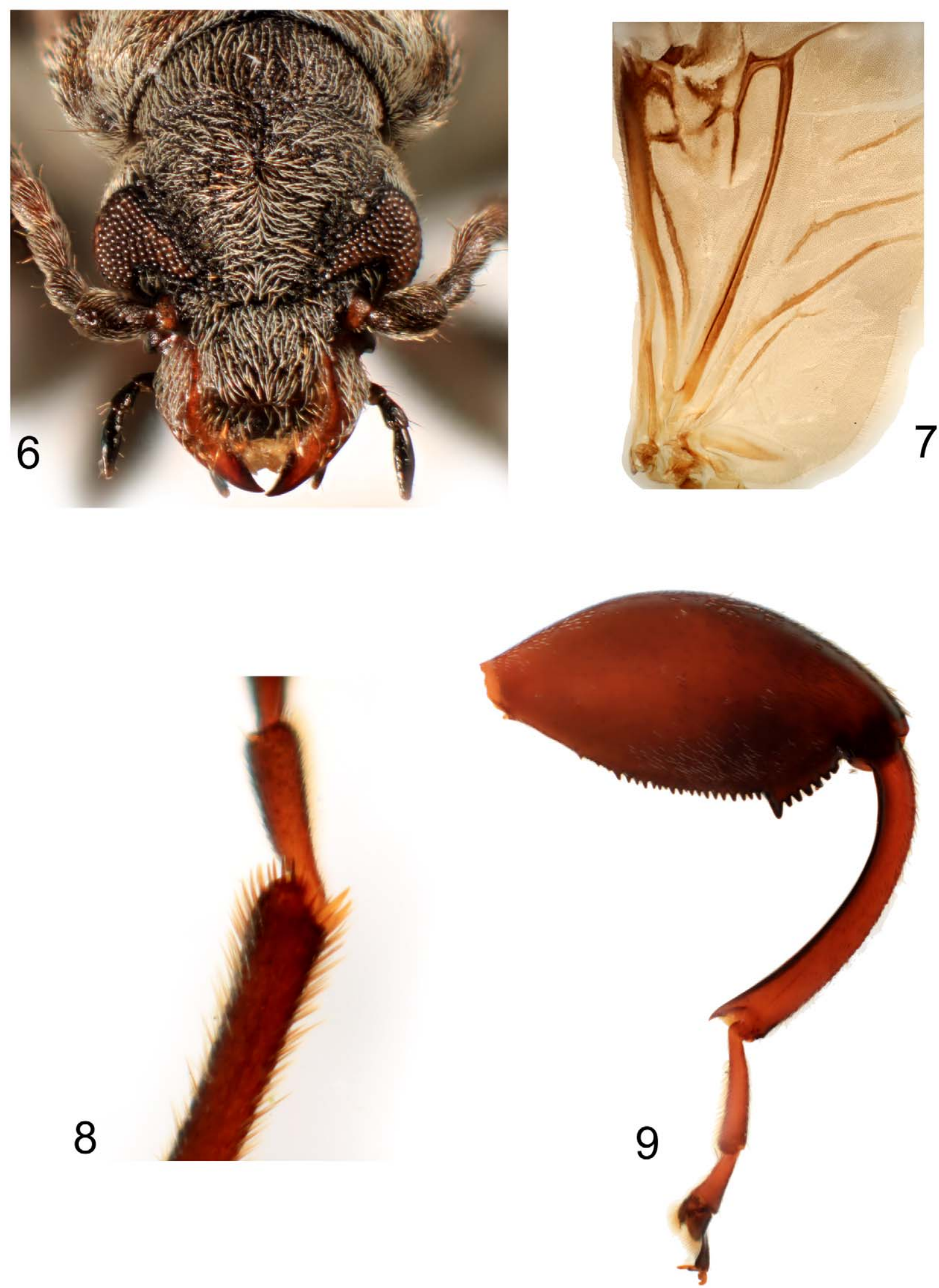

FIGURES 6-9. Buburra jeanae Reid \& Beatson: 6, head; 7, base of wing; 8 apex mid tibia; 9, hind leg. 


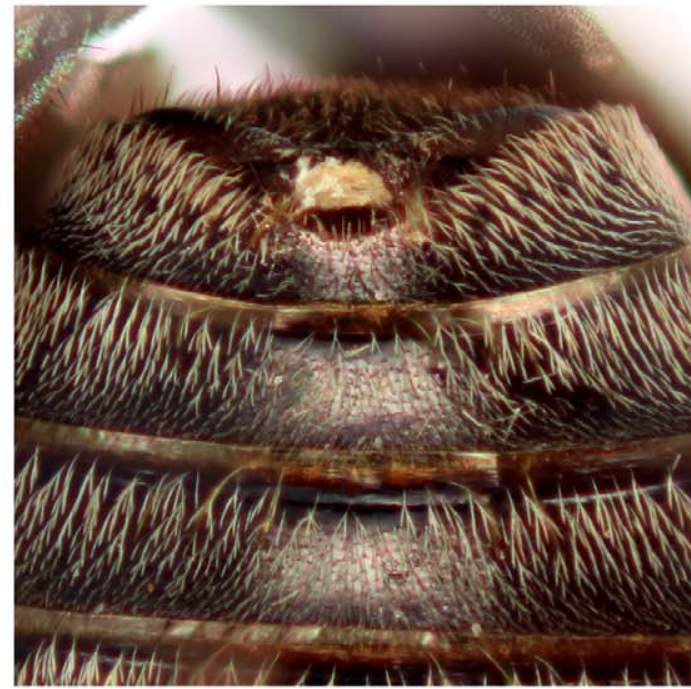

10

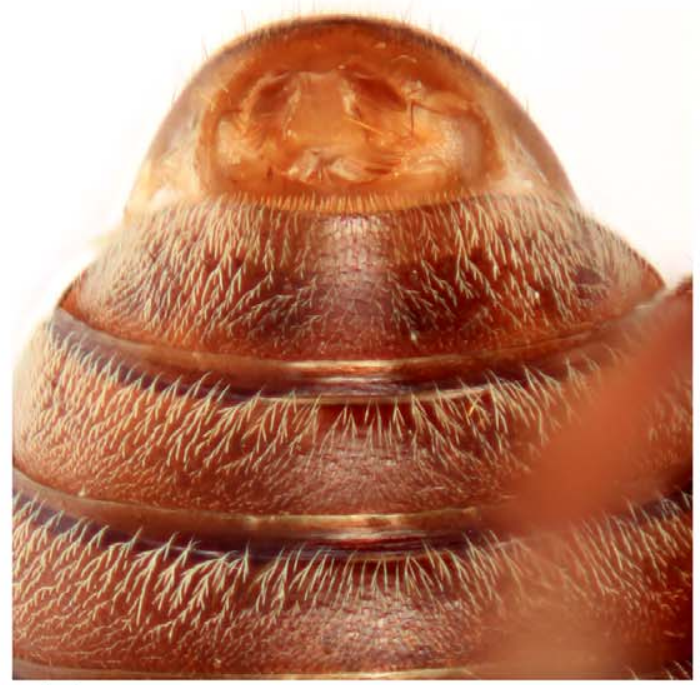

11

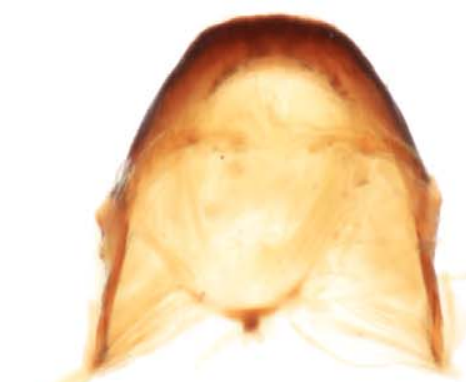

12
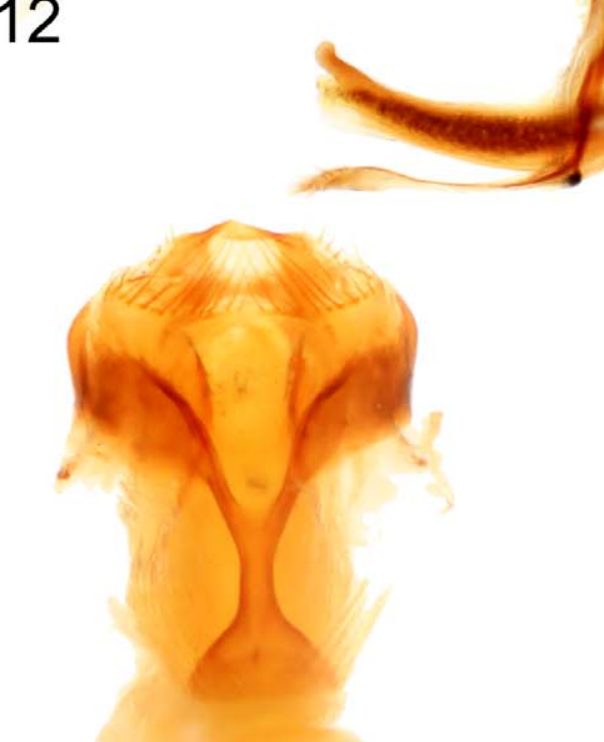

15

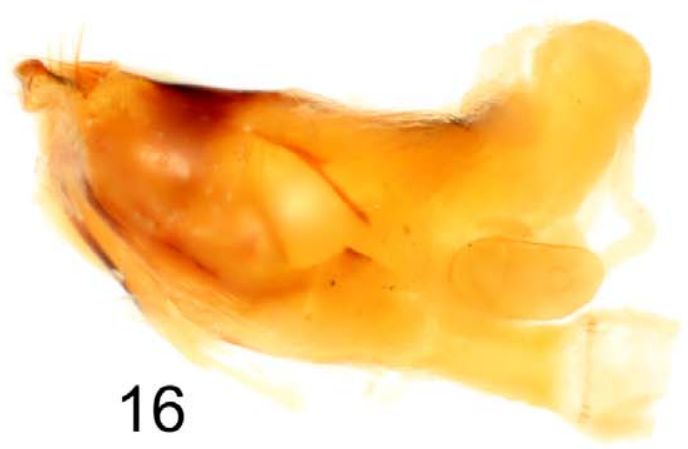

FIGURES 10-16. Buburra jeanae Reid \& Beatson: 10, venter male abdomen; 11, venter female abdomen; 12 , male tergite and sternite $8 ; 13$, lateral male genitalia (in fluid); 14, apicolateral male genitalia (dry); 15, ovipositor, ventral; 16, ovipositor, lateral. 
Abdomen (Figs 3, 10, 11): pygidium slightly transverse, shape acutely triangle but with tip rounded off (male $=$ female); first ventrite as long as $2-4$ combined; male last ventrite apex shallowly concave at middle; female last ventrite apex evenly convex.

Male genitalia (Figs 12-14, 19-21): apex tergite 8 truncate; sternite 8 minute and Y-shaped; apical lobes tegmen fused, membranous, bilobed and setose at apex, basal strut thin, with low external keel in basal half; penis parallel-sided, not greatly expanded at middle, apex reflexed, acute, rigid (strongly sclerotised), without separately sclerotised 'valves'; endophallus with dense granular microtubercles in two confused rows, from middle to apex of penis.

Female genitalia (Figs 15-16, 22-25): ovipositor relatively short; tergite 8 sclerotised across middle and at apex, slightly longer than broad, with strongly concave inner edge and convex apex; sternite 8 strongly sclerotised except middle and apex, transverse, with elongate-triangular truncate spiculum and apical row of long setae; vaginal palpi weakly sclerotised, almost spherical, papillate with 3 long apical setae, each attached internally to long baculus; paraprocts and proctiger weakly sclerotised, poorly demarcated; spermatheca C-shaped, with invagination at entry of duct.

Sexual dimorphism. Sexual dimorphism is slight: antennal proportions similar but male antennae slightly larger (Figs 17-18); elytra generally covering more of pygidium in male; apex male ventrite V slightly concave, apex female ventrite $\mathrm{V}$ convex (Figs 10-11).

Distribution and biology. This genus is known from a single species at a single locality in the Victorian Alps, south-east Australia. The larval host is unknown but possibly Acacia alpina (Fabaceae). See notes under species description for further discussion.

Etymology. Buburra is a recorded name for 'mountain' in the extinct language Waywurru (also known as Pallanganmiddang), endemic to the region of occurrence (Blake \& Reid 1999). The gender is to be treated as feminine.

Notes. Buburra shows several plesiomorphic features for a bruchine, by comparison with the sister-group Sagrinae (Reid 1995, 2000), including: head not abruptly constricted behind vertex; frons without ridge; antennae not sexually dimorphic; prosternal process strongly arched between coxae and meeting hypomeral lobes behind coxae; smooth pronotum and elytra; scutellum triangular; broad mesepimera; relatively complete medial wing venation; 2 apical spurs on anterior and mid tibiae; tibiae without prominent lateral keels; penis strongly sclerotised at tip, without discrete apical sclerites ('valves': Nilsson \& Johnson 1993, figure 117) ; endophallus without spines or large sclerites; tegmen without gemmae; ovipositor short, including wellsclerotised female sternite VIII, with short and broad apodeme; bursa copulatrix without spines. The lateral margination of the pronotum cannot be considered plesiomorphic as it shows multiple gains or losses in Chrysomelidae (Reid 1995). Buburra shows few apomorphies within Bruchinae, including: long temples; pectinate hind femur; tegminal strut keeled on external surface. The combination of attributes places Buburra in Pachymerini, a tribe defined by a plesiomorphy and body and appendage ratios and therefore likely to be paraor polyphyletic.

There are reviews of the anatomy of all genera of Pachymerini (Nilsson \& Johnson 1993; Johnson, Southgate \& Delobel 2004). A Cretaceous fossil has also been placed in Pachymerini (Reid 2000; Poinar 2005). Comparing Buburra with other Pachymerini we are unable to find any obvious relationship to other genera; the differences in head capsule, tibiae and male and female genitalia are particularly striking. Buburra seems to be an isolated taxon in the Pachymerini and provides further evidence for the non-monophyly of the tribe.

\section{Buburra jeanae Reid \& Beatson, sp. nov.}

Material examined. Holotype: $7 /$ VICTORIA, Mt Buffalo NP, top of Dixon's Falls, c1455m, 36:46:29S 146:47:42E, Phebalium squamulosum ssp alpinum flws, 15.xi.2010, C. Reid (AMS); Paratypes (9): 4 (2ð, 2ᄋ) same data as holotype (AMS, MHNP); 10,1 , , same data as holotype except beating Phebalium squamulosum ssp alpinum flowers, 29.xi.2011, (AMS, ANIC); 10 , 2 9 , ditto except sweeping Acacia alpina with small seedpods (MVM, AMS).

Description. As for genus, plus the following details of colour and sculpture: 


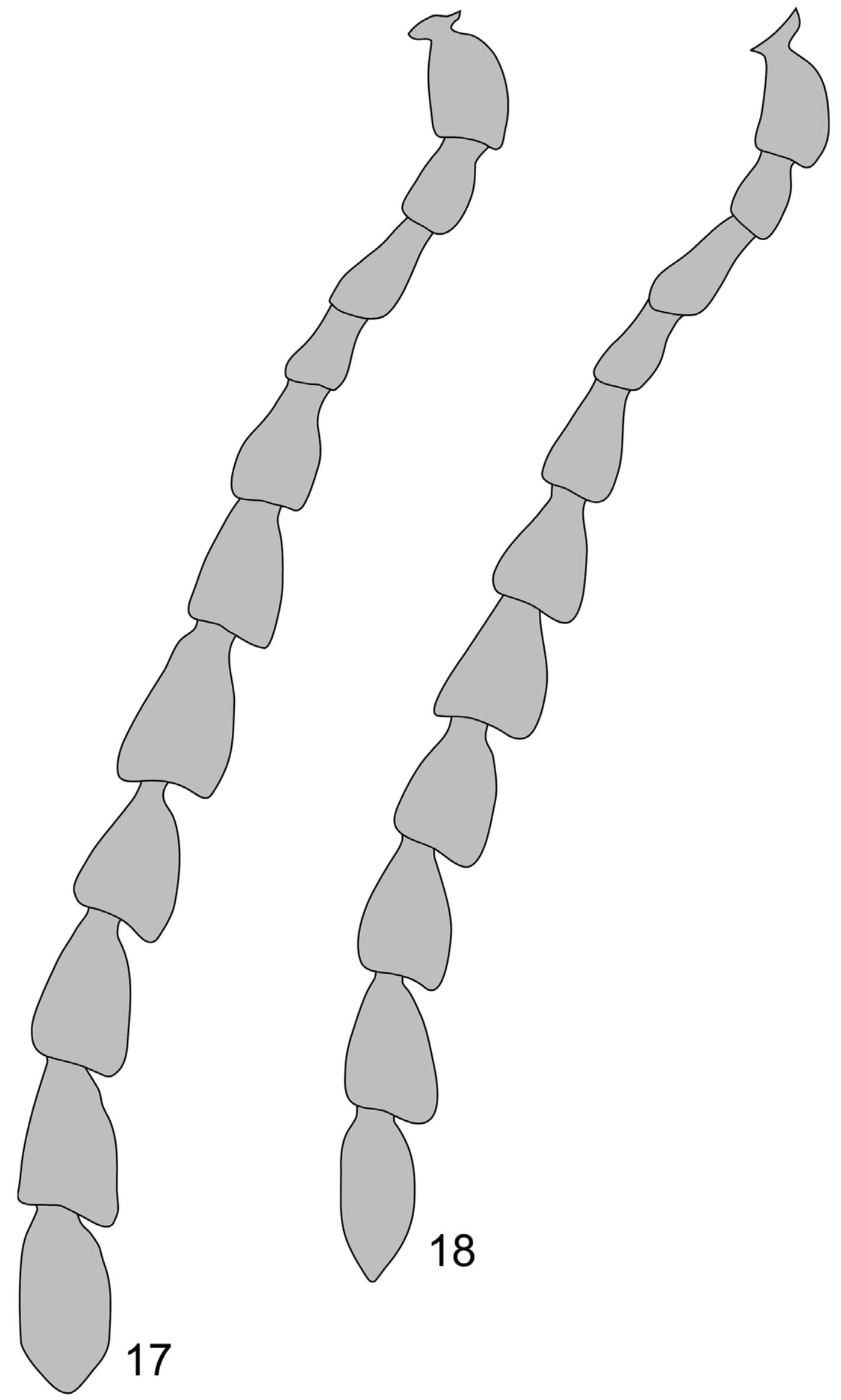

FIGURES 17-18. Buburra jeanae Reid \& Beatson: 17, male antenna; 18, female antenna. Drawn to scale. 


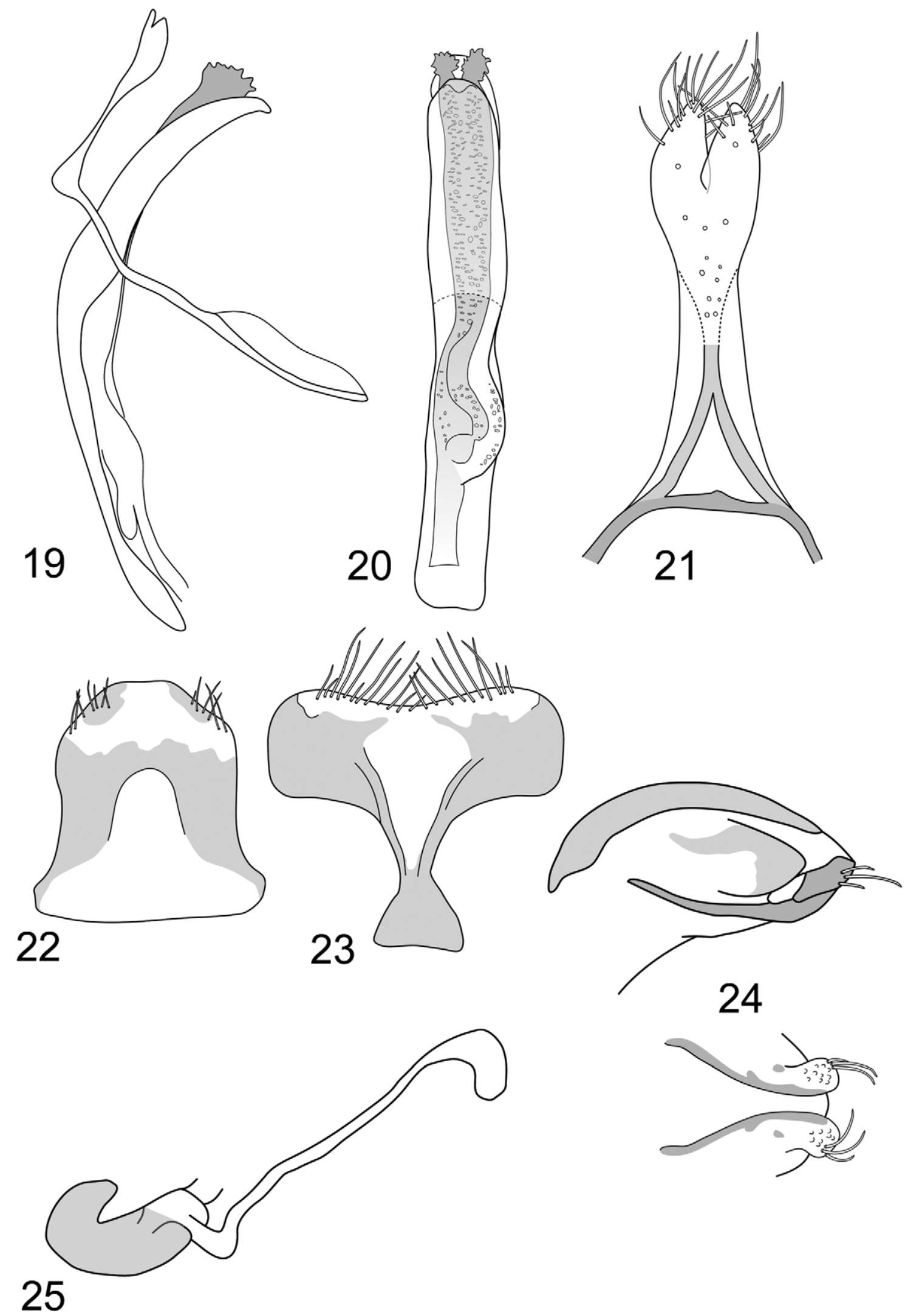

FIGURES 19-25. Buburra jeanae Reid \& Beatson, genitalia drawn from cleared specimens: 19, lateral penis and tegmen; 20 , ventral penis; 21, apex tegmen; 22, female tergite VIII; 23, female sternite VIII; 24, ovipositor lateral and apicoventral; 25, spermatheca and gland. 
Colour (Figs 2-6) variable irrespective of sex. Darkest form dark-reddish-brown except the following black to blackish-brown: antennomeres 1-2, 6-11, palpi, dorsum of head, disc and anterior of pronotum, prosternum, mesoventrite, metaventrite, anterior and mid coxae and femora (except bases), apical halves ventrites; and the following clear reddish-brown: venter head capsule, mandibles, hypomeral lobes, hind tibiae, ventrite basal halves; the elytra are variegated blackish- and reddish-brown. Palest form clear reddish-brown except the following black to blackish-brown: frons and base of clypeus, palpi, antennomeres 6-11 and apical half 5; prosternal process; and the following dark reddish-brown: anterior pronotum, elytral humeri and patch around scutellum, band across middle metaventrite, apical halves anterior and mid tibiae, sides pygidium, narrow apices ventrites. Elytra variegated clear and dark reddish-brown.

Surface sculpture (Figs 2-6): frons and vertex dull, densely finely punctured and microreticulate, with close adpressed pale setae; with larger punctures and erect setae around inner margin of eye; clypeus microreticulate and finely punctured, with pale adpressed setae; labrum setose but shining; all antennomeres dull, microreticulate and densely setose, but 5-11 more so than 1-4; venter of head dull (punctured, setose and microreticulate) from between temples to mentum, smooth and shining (without sculpture) posterior to this; pronotum dull, densely finely punctured, microreticulate and setose with pale adpressed setae and scattered dark erect setae; prosternum and hypomeron with dense adpressed pale setae; scutellum with dense adpressed pale setae; elytra sculptured as pronotum except shining, without distinct microreticulation, and adpressed setae in small variegated patches of pale cream thicker stae or black thinner setae; pygidium sculptured as elytra, with dense adpressed pale setae, denser along midline; ventrites sculptured as dorsum except slightly smoother and shinier between punctures, dense adpressed pale setae; scattered erect dark setae present on legs; anterior and mid femora densely setose with adpressed pale setae; hind femora with variegated pale and dark adpressed setae, as elytra; anterior and mid tibiae with mixed pale and dark setae, more erect towards apices; hind tibia and tarsi with adpressed pale setae.

Distribution and biology. The species has been collected only in November, at a single site in the Victorian Alps, Mount Buffalo National Park. This is an isolated granite mountain range rising to $1723 \mathrm{~m}$. Within the park, Buburra jeanae was only collected along the last $200 \mathrm{~m}$ of walking track above Dixons Falls, in the dominant plateau vegetation classified as "subalpine woodland and open forest" (Anonymous 2001), although the site is complex as it includes streamside communities and rocky areas near the top of a steep slope (Fig. 1). Buburra jeanae was not found at other collecting sites in the park in November 2010 and November 2011: the first $1.2 \mathrm{~km}$ of the Dixons Falls track, roadside $1 \mathrm{~km}$ NE of The Horn, The Castle, Dingo Dell, The Monolith, Crystal Brook Falls, several stops on the entrance road.

Adults of B. jeanae were first collected by beating flowering Phebalium squamulosum ssp alpinum (Rutaceae), where they were probably feeding on pollen, but this plant does not have seedpods suitable for the larva. Bruchines were absent from another species of Rutaceae flowering nearby, Boronia algida. There were two species of woody Fabaceae at the locality: Boissiaea foliosa, which was flowering, and the dwarf shrub Acacia alpina, which had young seedpods. There were no bruchines on Boissiaea (only cryptocephalines), but three adults of Buburra were collected by beating and sweeping the Acacia alpina on the second visit and we suspect that A. alpina is the larval host of this beetle.

Acacia alpina is widespread in the Australian Alps, from the western border of the Australian Capital Territory to central Victoria (Costermans 2009; Atlas of Living Australia 2012). Visits were made in November 2011 to nearby mountain peaks in the Victorian Alps, around Hotham Heights (where A. alpina occurs) and Falls Creek (A. alpina absent), but the weather was poor (continuous rain or southerly wind) and no bruchines were collected.

Two of the 10 specimens of $B$. jeanae have partially deformed antennae (each with 2 segments fused on one antenna), and there is also asymmetry in the anastomosed elytral striae, suggesting a genetic problem in this limited and isolated population.

Etymology. Named for CAMR's mother, in memory of a beautiful day on Mount Buffalo celebrating her birthday.

\section{Key to genera of Bruchinae in Australia}

The Australian literature is seriously out of date, because there have been no keys to genera or species of Bruchinae in Australia for more than 100 years (Lea 1899), except to the small South Australian fauna (Matthews \& Reid 
2002). During that time generic concepts have radically changed (Borowiec 1987) and several exotic genera have been introduced for biocontrol of weeds (Julien, McFadyen \& Cullen 2012). This key is based on all known established genera, exotic or native, which are as follows: Acanthoscelides Schilsky, 1905, with four introduced species (Raghu, Wiltshire \& Dhileepan 2005; Heard 2012); Algarobius Bridwell, 1946, with two introduced species (van Klinken 2012); Bruchidius Schilsky, 1905, a large and polyphyletic taxon (Southgate 1979; Kergoat $e t$ al. 2011), with nine native species including five hereby transferred from Bruchus based on examination of types in SAM (Bruchidius diversipes (Lea, 1899) comb. nov., B. maestus (Lea, 1899) comb. nov., B. oodnadattae (Blackburn, 1900) comb. nov., B. persimulans (Blackburn, 1900) comb. nov., B. quornensis (Blackburn, 1900) comb. nov.), and three exotic species (Southgate 1979; Palmer, Lockett \& Dileepan 2012); Bruchus Linneus, 1767, with one exotic species (Matthews \& Reid 2002); Callosobruchus Pic, 1902, with two exotic and one indigenous species (Anton 2000; Lambrides \& Imrie 2000); Caryedon Schoenherr, 1823, with one introduced species (Delobel et al. 2003); Mimosestes Bridwell, 1946, with one introduced species, which may have died out (van Klinken \& Heard 2012); Parasulcobruchus Anton, 1999c, a recently erected genus poorly differentiated from Bruchidius as understood here, with one endemic species (Anton 1999c); Penthobruchus Kingsolver, 1973, with one introduced species (van Klinken \& Heard 2012); Spermophagus Schoenherr, 1833, with two species, one introduced (Borowiec 1991; Anton 1999b). To these we add Caryotrypes Decelle, 1968, based on a single specimen collected on Lizard Island, Queensland, in 1993. Caryotrypes is a south Asian genus of two species, one of which has been bred from Pandanus seeds (Blanchard 1845; Decelle 1968; Anton 1999a), suggesting a link to the palm-feeding pachymerines of South America.

Quarantine interceptions of other genera are excluded from this key, as they are numerous and do not represent established species. These genera include (pers. obs., CAMR): Amblycerus Thunberg, 1815, Caryedes Hummel, 1827, Caryobruchus Bridwell, 1929, Megabruchidius Borowiec, 1984, Pachymerus Thunberg, 1805, Specularius Bridwell, 1938, Stator Bridwell, 1946, Zabrotes Horn, 1885. A failed introduction, of Meibomeus Bridwell, 1946 (Julien 2002), is also excluded from this key.

The key is has been constructed from examination of all known species present in Australia. $*=$ introduced (exotic) genus.

1. Ventral surface of hind femur with a well-developed preapical comb (pecten), with $>5$ teeth $\ldots \ldots \ldots \ldots \ldots$

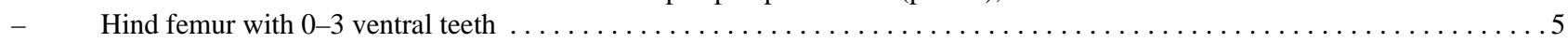

2(1). Prosternal process short and triangular, not visible between coxae; pro and mesotibiae with $0-1$ apical spur; frons with strong

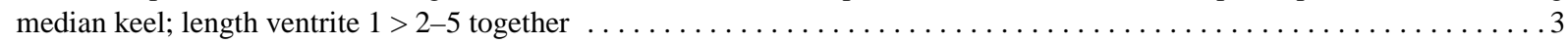
Prosternal process parallel-sided, visible between coxae; pro and mesotibiae with 2 apical spurs; frons without median keel; length ventrite $1=2-4$ together (lateral margins pronotum complete; Victorian Alps) $\ldots . . . \ldots \ldots$. . . . Buburra gen. nov.

3(2). Eyes massive, separated by $0.2-0.3 x$ eye width in dorsal view, with large facets; antennomeres 5-10 serrate, elongate; dorsal pubescence uniform, sculpture not rugose; abdomen uniformly setose; pro and mid tibiae with 1 apical spur ..........4 Eyes smaller, separated by c. $0.5 x$ eye width, with small facets; antennomeres 5-10 not serrate, transverse; sides pronotum concave; dorsal pubescence variegated, surfaces rugose; abdomen with smooth shining unsculptured areas (specula); pro and

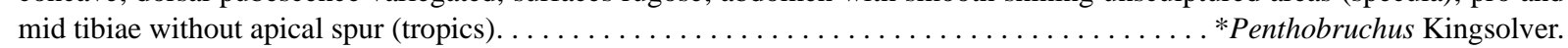

4(3). Pronotum widest at middle, with obtuse hind angles; pronotal lateral margination complete, but anterior third obscured by setae and puncturation; eyes smaller, separated by c.0.3 eye width (North Queensland) . . . . . . . . . . Caryotrypes Decelle. Pronotum widest at base, with $90^{\circ}$ hind angles, contracted to anterior margin; pronotal lateral margination absent from anterior

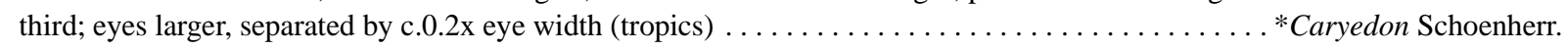

5(1). Hind tibia without apical spurs; apex scutellum bilobed or truncate; lateral margins of pronotum absent in apical half at least .... 6

- $\quad$ Hind tibia with 2 conspicuous apical spurs; scutellum triangular; lateral margins pronotum complete; hind femora without ventral teeth (flat, ovate species, mostly black; Queensland) . . . . . . . . . . . . . . . . . Spermophagus Schoenherr.

6(5). Lateral pronotal margin smoothly concave to convex; venter of hind femora without teeth or with tooth on internal margin or

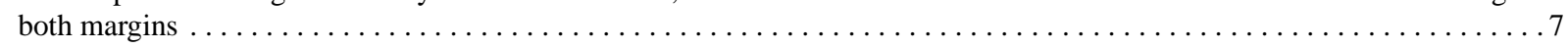

- $\quad$ Lateral pronotal margin with blunt tubercle (may be obscured by setae); venter of hind femur with large preapical tooth on outer margin (antennomeres $7-10$ not serrate; field crop pest) . . . . . . . . . . . . . . . . . . * Bruchus Linnaeus.

7(6). Venter of hind femur without tooth on outer margin; posterior margin of pronotum truncate or feebly concave ..........8 Venter of hind femora with single tooth on both internal and external margins; posterior margin of pronotum bilobed at junction with scutellum (males with serrate or flabellate antennae; tropics and stored products pest). . . . . . . Callosobruchus Pic.

8(7). Venter of hind femur with 3 distinct preapical teeth, proximal tooth much larger than others. . . . . . . . . . . . . . 9

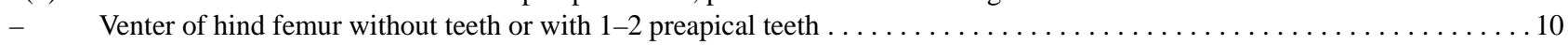

9(8). Hind tibia with longer apical spine, approximately as long as apical width of tibia; scutellum elongate, less deeply bilobed; base of elytron with small elevated shining denticles; female pygidium with two elongate glabrous patches (tropics) ........ *Algarobius Bridwell. Hind tibia with shorter apical spine, approximately half apical width tibia; scutellum quadrate, more deeply bilobed; base of 
elytron without elevated shining denticles; female pygidium uniformly setose (stored products pest) $\ldots \ldots \ldots \ldots \ldots$

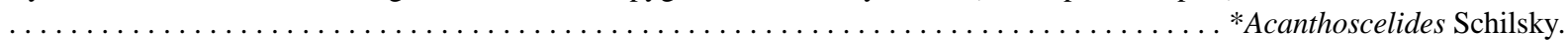

10(8). Without distinctive high contrast colour pattern, mostly uniformly greyish or brown or slightly variegated (venter of hund

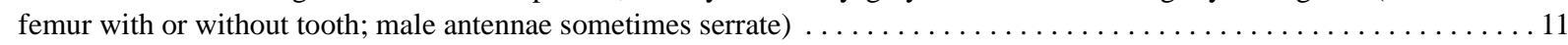
With distinctive colour pattern: head, pronotum, inner part of elytra, venter and legs clothed in dense white setae, outer part of elytra with contrasting black setae (venter of hind femur with small blunt preapical tooth; antennae not serrate; tropics).....

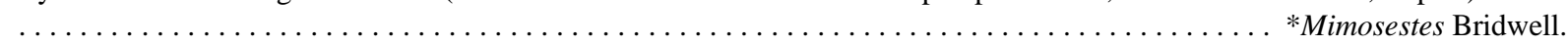

11(10). Apicodorsal hind tibial spines longer than apicolateral and apicoventral spines (hind femur with large preapical ventral tooth;

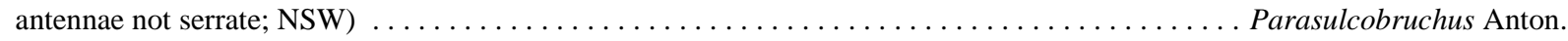
Apicodorsal hind tibial spines shorter than apicolateral and apicoventral spines (hind femur with or without preapical ventral tooth; antennae variable; throughout Australia $\ldots \ldots \ldots \ldots \ldots \ldots \ldots \ldots \ldots \ldots \ldots \ldots \ldots \ldots \ldots \ldots \ldots \ldots$ Bruchius Schilsky.

\section{Acknowledgments}

We are grateful to Adam Slipinski and Kate Lehmann (CSIRO, Canberra), and Elaine Tou and John MacDonald (Department of Agriculture, Fisheries and Forestry, Sydney), for the loan of material. We thank Jan Forrest and Peter Hudson for allowing CAMR access to the Lea and Blackburn material in SAM. Gael Kergoat and Midori Tuda provided helpful comments. CAMR thanks Parks Victoria for permission to collect at Mount Buffalo and for their interest in this beetle. He also thanks his family for their patience during holidays (twice) and his Mother for Figure 1.

\section{References}

Anonymous (2001) Mount Buffalo Plateau vegetation map and guide. Parks Victoria, Melbourne. [unpaginated folding map] Anton, K.-W. (1999a) Notes on Caryotrypes Decelle, with the description of a new species (Coleoptera: Bruchidae: Pachymerinae). Genus, 10(1), 59-63.

Anton, K.-W. (1999b) Three new species of Spermophagus Schoenherr, 1833, from Thailand, with notes on synonymy of $S$. perpastus (Lea) (Coleoptera: Bruchidae: Amblycerinae). Genus, 10(1), 73-80.

Anton, K.-W. (1999c) Revision of the genus Sulcobruchus Chujo 1937, and description of Parasulcobruchus nov. gen. (Coleoptera, Bruchidae, Bruchinae). Linzer biologische Beitrage, 31(2), 629-650.

Anton, K.-W. (2000) Five new species of the Callosobruchus chinensis group from the Oriental Region and Australia (Coleoptera: Bruchidae: Bruchinae). Genus, 11(1), 13-28.

Anton, K.-W. \& Delobel, A. (2003) African species of the Bruchidius centromaculatus group with "eyed" female pygidium (Coleoptera; Bruchidae: Bruchinae). Genus, 14, 159-190.

Atlas of Living Australia (2012) Acacia alpina: alpine wattle. http://bie.ala.org.au/species/Acacia+alpina (accessed August 2012)

Blackburn, T. (1900) Further notes on Australian Coleoptera, with descriptions of new genera and species, 26. Transactions of the royal Society of South Australia, 24, 35-68.

Blake, B.J. \& Reid, J. (1999) Pallanganmiddang: a language of the Upper Murray. Aboriginal History, 23, 15-31.

Blanchard, C.E. (1845) Communications. Bruchus (Pachymerus) pandani. Annales de la Sociétè entomologique de France, 3(2), IV-V.

Borowiec, L. (1987) The genera of seed beetles (Coleoptera, Bruchidae). Polskie Pismo Entomologiczne, 57, 3-207.

Borowiec, L. (1991) Revision of the genus Spermophagus Schoenherr (Coleoptera: Bruchidae: Amblycerinae). Genus (unnumbered supplement), 1-198.

Brooks, JG. (1969) Records of Coleoptera from Australia. Journal of the Australian entomological Society, 8, $211-2$. http://dx.doi.org/10.1111/j.1440-6055.1969.tb00759.x

Costermans, L.F. (2009) Native trees and shrubs of southeastern Australia. Reed New Holland, Melbourne, 432pp.

Decelle, J. (1968) Nouveaux genres et especes de Caryedontini (Col. Bruchidae Pachymerinae) d'Afrique et de Madagascar. Bulletin et Annales de la Société royale d'entomologie de Belgique, 104, 413-426.

Delobel, A. \& Legalov, A. (2009) A new species of Kytorhinus Fisch.-Wald. from Western Pamir (Coleoptera: Bruchinae). Genus, 20(1), 71-6.

Delobel, A., Sembène, M., Fédière, G. \& Roguet, D. (2003) Identity of the groundnut and tamarind seed-beetles (Coleoptera: Bruchidae: Pachymerinae), with the restoration of Caryedon gonagra (F.). Annales de la Sociétè entomologique de France, 39(3), 197-206.

Grey, P. \& Grey, M. (1998) (eds) Mount Buffalo centenary issue. The Victorian Naturalist, 115(5), 157-256, plates 1-7.

Heard, T.A. (2012) Mimosa pigra L. - mimosa. pp. 378-397, in: Julien, M., McFadyen, R. \& Cullen, J. (eds) Biological control of weeds in Australia. CSIRO Publishing, Melbourne.

Johnson, C.D. (1983) Ecosystematics of Acanthoscelides (Coleoptera: Bruchidae) of southern Mexico and Central America. Miscellaneous Publications of the American entomological Society, 56, 1-370. 
Johnson, C.D., Southgate, B.J. \& Delobel, A. (2004) A revision of the Caryedontini (Coleoptera: Bruchidae: Pachymerinae) of Africa and the Middle East. Memoirs of the American entomological Society, 44, 1-120.

Julien, M.H. \& Griffiths, M. W. (1998) Biological control of weeds: a world catalogue of agents and their target weeds, $4^{\text {th }}$ edition. CABI Publishing, Wallingford, $223 \mathrm{pp}$.

Julien, M., McFadyen, R. \& Cullen, J. (2012) Biological control of weeds in Australia. CSIRO Publishing, Melbourne, 648pp.

Kergoat, G., Delobel, A., Le Ru, B. \& Silvain, J.-F. (2008) Seed beetles in the age of the molecule: recent advances on systematics and host-plant association patterns, pp. 59-86 in: Jolivet, P., Santiago-Blay, J. \& Schmitt, M. (eds) Research on Chrysomelidae Volume 1, Brill, Leiden.

Kergoat, G.J., Le Ru, B.P., Genson, G., Cruaud, C., Couloux, A. \& Delobel, A. (2011) Phylogenetics, species boundaries and timing of resource tracking in a highly specialized group of seed beetle (Coleoptera: Chrysomelidae: Bruchinae). Molecular Phylogenetics \& Evolution, 59, 746-760. http://dx.doi.org/10.1016/j.ympev.2011.03.014

Kingsolver, J.M. (1971) Description of a new seed beetle from Australia (Coleoptera: Bruchidae). Journal of the Australian entomological Society, 10, 179-182. http://dx.doi.org/10.1111/j.1440-6055.1971.tb00029.x

van Klinken, R.D. (2012) Prosopis spp. - mesquite. pp. 477-485, in: Julien, M., McFadyen, R. \& Cullen, J. (eds) Biological control of weeds in Australia. CSIRO Publishing, Melbourne.

van Klinken, R.D. \& Heard, T.A. (2012) Parkinsonia aculeata L. - parkinsonia. pp. 437-447, in: Julien, M., McFadyen, R. \& Cullen, J. (eds) Biological control of weeds in Australia. CSIRO Publishing, Melbourne.

Lambrides, C.J. \& Imrie, B.C. (2000) Susceptibility of mungbean varieties to the bruchid species Callosobruchus maculatus (F.), C. phaseoli (Gyll.), C. chinensis (L.) and Acanthoscelides obtectus (Say) (Coleoptera: Chrysomelidae). Australian Journal of Agricultural Research, 51(1), 85-90. http://dx.doi.org/10.1071/AR99051

Lawrence, J.F., Beutel, R.G., Leschen, R.A.B. \& Slipinski, S. A. (2010) Chapter 2. Glossary of Morphological Terms. pp. 9-20. In: Leschen, R.A.B., Beutel, R.G. \& J.F. Lawrence (eds.). Handbook of Zoology, Coleoptera Volume 2: Morphology and Systematics (Elateroidea, Bostrichformia, Cucujiformia partim). Walter de Gruyter, Berlin.

Lea, A.M. (1898) Descriptions of new species of Australian Coleoptera, part 5. Proceedings of the Linnean Society of New South Wales, 23, 521-645.

Matthews, E.G. \& Reid, C.A.M. (2002) A guide to the beetles of South Australia, part 8. Polyphaga: Chrysomeloidea: Chrysomelidae. South Australian Museum, Adelaide, 64pp.

Nilsson, J.A. \& Johnson, C.D. (1993) A taxonomic revision of the palm bruchids (Pachymerinae) and a description of the world genera of Pachymerinae. Memoirs of the American entomological Society, 41, 1-104.

Orchard, A.E. (1999) Introduction. Flora of Australia, 1 ( $3^{\text {rd }}$ edition), 1-11.

Palmer, B., Lockett, C. \& Dileepan, K. (2012) Acacia nilotica subsp. indica (Benth.) Brenan - prickly acacia. pp. 18-28 in: Julien, M., McFadyen, R. \& Cullen, J. (eds) Biological control of weeds in Australia. CSIRO Publishing, Melbourne.

Poinar, G. (2005) A cretaceous palm bruchid, Mesopachymerus antiqua, n. gen., n. sp. (Coleoptera: Bruchidae: Pachymerini) and biogeographical implications. Proceedings of the entomological Society of Washington, 107(2), 392-397.

Reid, C.A.M. (1995) A cladistic analysis of subfamilial relationships in the Chrysomelidae sensu lato (Chrysomeloidea), pp. 559-631, in Pakaluk, J. \& Slipinski, S.A. (eds) Biology, phylogeny and classification of Coleoptera. Papers celebrating the 80th birthday of Roy A. Crowson. Muzeum i Instytut Zoologii PAN, Warszawa.

Reid, C.A.M. (2000) Spilopyrinae Chapuis: a new subfamily in the Chrysomelidae and its systematic placement (Coleoptera). Invertebrate Taxonomy, 14, 837-862. http://dx.doi.org/10.1071/IT00042

Southgate, B.J. (1979) Biology of the Bruchidae. Annual Review of Entomology, 24, 449-473. http://dx.doi.org/10.1146/ annurev.en.24.010179.002313

Udayagiri, S. \& Wadhi, S.R. (1989) Catalog of Bruchidae. Memoirs of the American entomological Institute, 45, 1-301.

\section{Appendix A. Checklist of Australian Bruchinae.}

$*=$ introduced genus or species. References are provided for first records in Australia. This checklist ignores the extensive extralimital synonymy.

Bruchini Latreille 1802: 192

*Acanthoscelides Schilsky 1905: C

*macrophthalmus (Schaeffer 1907: 300; Bruchus); Raghu, Wiltshire \& Dhileepan 2005: 311 (Australia)

*obtectus (Say 1831: 1; Bruchus); Lea 1899: 637 (Australia)

*puniceus Johnson 1983: 167; Julien \& Griffiths 1999: 75 (Australia)

*quadridentatus (Schaeffer 1907: 304; Bruchus); Julien \& Griffiths 1999: 76 (Australia)

*Algarobius Bridwell 1946: 54

*bottimeri Kingsolver 1972: 116; Donnelly 2002: 404 (Australia)

*prosopis (LeConte 1858: 77; Bruchus); Julien \& Griffiths 1999: 77 (Australia) 
Bruchidius Schilsky 1905: B

*centromaculatus (Allard 1868: 20; Bruchus)

= sahlbergi Schilsky 1905: 94; Julien \& Griffiths 1999: 74 (Australia); Anton \& Delobel 2003: 161 (synonymy)

despicatus (Lea 1899: 639; Bruchus)

diversipes (Lea 1899: 640; Bruchus); comb. nov.

lyndhurstensis (Blackburn 1900: 62; Bruchus); Matthews \& Reid 2002: 47 (Bruchidius)

mackenziei Kingsolver 1971: 179

maestus (Lea 1899: 639; Bruchus); comb. nov.

modicus (Lea 1899: 640; Bruchus)

oodnadattae (Blackburn 1900: 63; Bruchus); comb. nov.

persimulans (Blackburn 1900: 64; Bruchus); comb. nov.

*quinqueguttatus (Olivier 1795: 15; Bruchus);

= *quadriguttatus (Boheman 1829: 111; Bruchus); Lea 1899: 637 (Australia); Southgate 1979: 454 (doubtful record)

quornensis (Blackburn 1900: 63; Bruchus); comb. nov.

*villosus (Fabricius 1792: 373; Bruchus); Julien \& Griffiths 1999: 65 (Australia)

*Bruchus Linneus 1767: 604

*pisorum (Linneus 1758: 356; Laria)

= *pisi Linneus 1767: 604; Lea 1899: 637 (Bruchus pyri [sic], B. pisi, Australia) Blackburn 1900: 64 (Bruchus pisi L; Australia)

Callosobruchus Pic 1902: 6

*chinensis (Linneus 1758: 386; Curculio); Lea 1899: 637 (Australia)

eremitus Anton 2000: 17

*maculatus (Fabricius 1775: 65; Bruchus); Lambrides \& Imrie 2000 (Australia)

*Mimosestes Bridwell 1946: 54

*ulkei (Horn 1873: 324, Bruchus); Julien \& Griffiths 1999: 49 (Australia)

Parasulcobruchus Anton 1999c: 641

semicalvus (Lea 1899: 638, Bruchus)

*Penthobruchus Kingsolver 1973: 142

*germaini (Pic 1894: 65; Pachimerus[sic]); Julien \& Griffiths 1999: 49 (Australia)

Amblycerini Bridwell 1932: 103

Spermophagus Schoenherr 1833: 102

perpastus Lea 1899: 638 (Bruchus); Anton 1999b: 79 (Spermophagus)

*sericeus (Geoffroy 1785: 112; Mylabris); Udayagiri \& Wadhi 1989: 28 (Australia)

Pachymerini Bridwell 1929: 142

Buburra Reid \& Beatson 2012

jeanae Reid \& Beatson 2012

*Caryedon Schoenherr 1823: 1134

* gonagra (Fabricius 1798: 159; Bruchus); Delobel, Sembene, Fediere \& Roguet 2003: 203 (Australia)

= serratus sensu auctt., nec (Olivier 1790: 199; Bruchus); Brooks 1969: 211 (Australia)

Caryotrypes Decelle 1968: 422

species unknown; Reid \& Beatson 2012 (Australia) 